\title{
Fate in the Religion of the Lepchas
}

\author{
FROM THE THIRD DANISH EXPEDITION TO \\ CENTRAL ASIA I $947-54$ \\ By HALFDAN SIIGER
}

The question of Fate in the religion of an indigenous culture faces us with many difficulties. This is probably first and foremost due to the fact that Fate, after all, is a problem belonging to the higher religions, and one in which certain theological and ethical notions play a prominent part. Fate in this special sense of the word presupposes a certain world order or plan which may be envisaged as a moral unity, intelligible to man. In any religion presupposing such a world order the question of Fate is apt to arise in the minds of the believers, as, for example, in Islam and Christianity.

Nevertheless, the question of Fate may also present itself to the more thoughtful members of some indigenous religions, although we must certainly in this case give a wider meaning to the word. When studying indigenous religions, we have to confine ourselves to the search for particular approaches to that constellation of problems which forms the prerequisite for the notion of Fate in the higher religions. That is to say, we must not expect any coherent, integrated system of thought.

In order to understand the problem of Fate among the Lepchas ${ }^{1}$ we must concentrate on their central religious experiences, on that which constitutes their world as a whole and which gives it its cosmic core, the very mainspring of its existence.

1 The Lepchas are mountainous agriculturalists who live in the State of Sikkim in the Himalayas and in some adjacent Indian districts. Cf. the present author's report: "Ethnological Field-Research in Chitral, Sikkim, and Assam", Det kongelige Danske Videnskabernes Selskab, vol. 36. No. 2, pp. 35-47, Copenhagen 1956. Cf. also Geoffrey Gorer, Himalayan Village, London 1938; John Morris, Living with Lepchas, London I 938 . 
To the Lepchas the world consists first of all of an innumerable number of living beings, i.e. benignant or maleficent supernatural beings, men, and animals. All these living beings live and act constantly on each other and frequently against each other. In other words, the world consists of an enormous number of life-functions, not only in the terrestrial sphere, but also in the supernatural sphere, for the supernatural sphere is just as much a part of the world of the Lepcha as is the terrestrial sphere. Among all these functions man has not only his own tiny daily activities, which he tries to adjust to the functions of Nature herself, but also a great number of more important activities, which he attempts to conduct according to the will of the beings of the supernatural sphere. For a foreigner it is often difficult to discover where the tiny activities end and the more important activities begin. To the mind of the Lepchas the problem of mankind is to bring his major activities in harmony with the supernatural order, and therefore his activities have both a terrestrial raison d'être and a supernatural raison d'être.

Similar conditions may, of course, also be observed among many other indigenous peoples. When the behaviour of indigenous man sometimes confuses the foreigner, it is often due to the fact that he does not take the above twofold aspect of activity into consideration. Except for very ordinary activities, indigenous man seldom does anything of importance without this double reference, i.e. without simultaneously having regard to the rules of the terrestrial sphere and to the rules of the supernatural sphere. The reason for this rests on the fact that indigenous man in his heart of hearts experiences the world as created by some of the supernatural beings to whom it therefore ultimately belongs. Man is only a tiny part of this created world, the society is a greater part, and mankind as such is the greatest part, but none of them stand outside the whole formed by the terrestrial and the supernatural spheres together. The Lepchas attempt to harmonise their major activities with the will of the supernatural beings by means of great 'ceremonial performances', which therefore must be said to constitute the very centre of their religious life. These ceremonial performances are extensive and complicated, just as the entire world is manifold and complicated, as it presents itself to him.

Let us give some examples. To the Lepchas the supernatural world is 
divided into two groups, the rumm, or the mainly benevolent supernatural beings, and the mung, or the malignant supernatural beings. Any evil occurrence is in the first instance ascribed to the malignant activities of the mung, but it may, under certain conditions, also be due to temporary ill-will on the part of some or other rum. If it is obvious that the evil occurrence is caused by a human being, this person is considered to be governed by some mung, or he may, which is much worse, be a mung in human disguise. At all events, any evil occurrence is experienced as the result of the evil will-power of some or other malignant supernatural being. Consequently, we cannot apply our technical term "Fate" to such occurrences, and Fate as an abstract concept cannot be used, when we speak of the Lepchas. To them there is no evil Fate per se. But daily life has numerous manifestations of evil willpower which have their origin in some or other supernatural being, and everyone has to be constantly on guard against these. That is, of course, particularly so for those who are specially exposed to the activity of evil will-power, such as pregnant women, a man going out hunting etc., but even a man who is going to build a house must take his precautions. Such people are therefore constantly looking for tiny hints in the life of Nature which may give them a warning that misfortune is in store for them. The ominous hint may be the appearance of a strangely coloured butterfly or bird, the call of an animal, the meeting of a person behaving unusually, etc. That is to say, any natural occurrence may, under certain circumstances, be taken as omens of future evil, they are portentous signals of something which will occur unless steps are taken to prevent it. In other words, the approach of an evil occurrence may be discovered by means of such small signals, and may then, perhaps, be avoided provided that the person concerned is able to interpret the ominous signal. Thus Fate in this connection becomes the sense of something potentially evil, which is approaching, but which may be avoided provided that the person is able to interpret the signals and to take the necessary precautions. But only the person who has received the right instruction from the elders of his people will know how rightly to interpret these signals. We might, perhaps, say that the ominous signal is the shadow of a foreboding fateful occurrence. But we should hesitate to use our term Fate in this connection, as fate which may be avoided is not an inescabable fate, resting on inevitable causal relations or on a divine decree. 
Horoscopes, probably of Tibetan origin, play an important role in the life of the Lepchas. A person's horoscope discloses the dependence of his life on the supernatural world, and the right interpretation of its diagram is a potential key to the knowledge of his fate.

It is the duty of the maker and reader of horoscopes to draw up the diagrams and to expound them. The Lepchas use both birth, marriage, and death horoscopes. In daily life horoscopes are much used when marriages are planned. If the horoscopes of the prospective spouses do not correspond favourably, there will be no marriage. If the horoscopes correspond favourably, the elder members of the families will give their consent to the marriage, sometimes even urging or forcing the young couple to marry without their having any mutual inclination to do so.

It is no wonder that horoscopes play an important role in the planning of marriages, because a marriage unites not only two persons, but also two families in the most intimate social way. But also from the religious point of view marriage constitutes a significant tie, because a marriage unites two persons' fates in such a way that the outcome may be either auspicious, or ominous, or mixed. At the contraction of a marriage two persons' fates are united in such a way that a marriage entails a conjunction of two fates which may determine not only the health and the length of the lives of each partner, but also the health and length of life of their children. As practically all Lepchas are married, the fate of the entire Lepcha society depends to no small extent on the fates of all the married couples.

However, the reader of horoscopes will also tell people what they should do in order to modify, change, or even avert an approaching evil fate. This is generally done by means of ceremonial performances, and thus there is still hope for the endangered. A person is not the complete and passive victim of his fate. Generally speaking, a person cannot escape the major outcome of his fate, but many minor consequences can be altered or modified. The latter depends on his willingness to learn from the diagram what he must do, or to put it in other words, he must learn how to cooperate with his fate in order to attain a tolerable compromise. A person's fate, as disclosed by the diagram, reveals the will of the mighty supernatural powers, but this will is not in every respect beyond the influence of human beings. The man who learns from the diagram of his horoscope, adjusts his life according to its 
forecasts, and honestly observes the necessary precautions may modfty his fate for the better. In other words, a man has to cooperate with his own fate in order to improve his life, and if he does not, he will come to experience an evil fate.

Among the Lepchas there are certain persons, called mün, who possess extraordinary abilities to communicate with the beings of the supernatural world. The female mün are especially strong, and are called in when difficult situations arise, e.g. in cases of disease, when all other means have proved ineffective. These women are also called for when a dead person's soul is going to be sent forth into the next world.

If a person is haunted by one or several mung, i.e. devils or demons, then as a last resort a female mŭn may be called in. When she arrives, she puts on her special dress, and begins a ceremonial performance, during which she requests her auxiliary supernatural beings to appear, and to assist her in fighting the evil supernatural beings haunting the man. Thus one group of supernatural beings fight another group, and the outcome of this fight will decide the fate of the person. Now it may happen that the miserable state of the haunted person is due to the fact that some or other wicked person, e.g. another female mŭn, on her own initiative has set the evil supernatural beings upon him. In that case, the assisting mün will try to mobilise all her auxiliary supernatural beings and request them to fight the malignant supernatural beings sent by the hostile mŭn. Consequently, a great battle between the two groups of supernatural beings may ensue, and the outcome of this battle depends on which of the two groups is the stronger.

This example shows that a man's fate may depend on the outcome of a battle in the supernatural world, but this outcome is also dependent on which of the two female mün has the stronger group of supernatural beings at her disposal. No wonder that the female mŭn with the best supernatural connections are much sought after.

With the Lepchas a belief in the reincarnation of the departed souls may be found, but I should, however, hesitate to state that it is common. It may have been introduced, or at least stressed, by the creed of the Tibetan lamas. I learnt of some few cases of reincarnation in the villages I investigated, and one villager informed me that the soul of a departed person may be found reincarnated in a newborn child, sometimes in an animal, and, but rarely, 
even in a mung. The last-mentioned had happened to the soul of a woman who had had a very bad reputation. As the evidences of a general belief in reincarnation are so rare I prefer to exclude this problem from the present discussion of Fate.

Finally, we shall investigate the great religious ceremonies, as these seem to throw an interesting light on the present problem. Apart from many minor ceremonies performed on behalf of the individual, there are during the year some major ceremonial performances which concern the whole village or even the whole society, and which are therefore performed regularly on its behalf. These performances are similar to those which we find with innumerable other indigenous peoples throughout the world. To the anthropologist there is nothing particularly new in them, but a careful examination of them may contribute to the understanding of Fate among the Lepchas.

On these occasions the mainly benevolent supernatural beings, the rüm, are approached and requested to grant the people certain favours, e.g. fertility to human beings, to cattle, or to the fields, protection against the evil supernatural beings, and the like. The mere fact that such performances take place indicates that there is a certain connection between human beings and supernatural beings, and that the latter can be influenced by the former. If it were not so, the performances would have no purpose at all. When we use the word performance it should not be taken in any mechanical sense of the word. Nothing in the world functions mechanically according to the mind of the Lepchas. But when we say that the Lepchas observe such performances meticulously, we must be careful to state what we mean. Their religious performances have reference not only to the supernatural beings, but also to their own souls. Therefore they utter their prayers during the performances. The souls of the Lepchas appeal to the souls of the supernatural beings. It is, so to speak, soul that speaks to soul; and in their prayers they put their very souls into the performances. The religious performances should thus be viewed as preparing the way for the wishes of their souls which find an outlet through their prayers. Usually the Lepchas do not utter a prayer except at a ceremonial performance and thus we should regard the ceremonial performance as being intended to set their souls free and orient them towards the souls of the supernatural beings. But this is to say that the ceremonial performance has a twofold purpose and direction; one concerns 
the souls of the supernatural beings and on concerns the souls of men. In fact, the very purpose of the ceremonial performance is to establish a cooperation between these two groups of souls. In other words, the ceremonial performance has two aspects, a supernatural one and a human one. By means of the ceremonial performance the souls of men are drawn into that auspicious minor cosmological activity which is the ceremonial performance. We call it a cosmological activity, because it is an activity which includes not only man, his body and his soul, but also the supernatural beings, and because it aims at achieving a result which cannot be obtained without the help of the supernatural beings, i.e. it involves the cosmos of indigenous man.

It is a well known fact that the direct purpose of the ceremonial performances of indigenous peoples is to secure greater 'life-power' in the widest sense of the word, and to avert anything which might diminish this lifepower. But this means that there must be a possibility of influencing the souls of the supernatural beings or, in other words, of expanding or intensifying the good happenings which occur to human beings, and of changing or modifying the bad ones. The attitude, underlying the human approach, has as a necessary prerequisite the concept that the supernatural beings have certain events in store for human beings, and the ceremonial performances presuppose that human beings are or may be able to influence supernatural beings so that the coming events may be more auspicious or less inauspicious. If we are at all justified in attributing such a semi-philosophical notion as the above to the ceremonial performances of the Lepchas, we may conclude that future events represent not merely an exertion of an arbitrary will-power on the part of the supernatural beings, but are, on the contrary, events of a mixed origin, emerging from that particular state of mind which supernatural beings are in when they have accepted the request of human beings. But that is to say that human beings may to a certain degree influence the character of the events that are in store for them, or, to use another term, they may cooperate with their fate.

These considerations show that we may speak of a notion of Fate among the Lepchas provided that we employ that term in a specially modified form. 'To the Lepchas, Fate is not a totality of future events apprehended as an inevitable necessity controlling all happenings. It is rather a multitude of events emerging from the beings of the supernatural world, and these 
events appear as the realisation of a supernatural will-power which has incorporated the wishes of human beings. Fate is therefore not to be considered as a long series of inevitable events, but rather as a multitude of events which mankind cannot escape, but which, in their supernatural origin, are constantly being created or re-created according to the influence of human beings on the supernatural beings. In short, to the Lepchas, Fate is not an inevitable necessity, but a supernatural possibility, and this trait of possibility in the character of Fate depends on the willingness on the part of the supernatural beings to remain favourable towards the ceremonial approaches of the human beings.

Thus we may conclude by saying that Fate, according to the religion of the Lepchas, is the multitude of future events which supernatural beings have in store for human beings, and that the character of these events is constantly being created or re-created according to the favourable or unfavourable response of the supernatural beings to the ceremonial approaches of the human beings. Consequently, man is not absolutely without any influence on his own Fate, for its character depends on two factors, and although man constitutes always the inferior factor, he is not left in a state without any hope at all. 